\title{
Ethanol reduces ripening of 'Royal Gala' apples stored in controlled atmosphere
}

\author{
ANDERSON WEBER ${ }^{1}$, AURI BRACKMANN ${ }^{2}$, VANDERLEI BOTH ${ }^{2}$, ELIZANDRA \\ P. PAVANELLO ${ }^{2}$, ROGERIO O. ANESE ${ }^{3}$ and MÁRCIO R.W. SCHORR ${ }^{2}$
${ }^{1}$ Federal University of the Southern Frontier, Plant Science Dept., BR 158, Km 7, 85301-970 Laranjeiras do Sul, PR, Brazil
${ }^{2}$ Postharvest Research Center, Plant Science Department, Federal University of Santa Maria/UFSM, 1000, 97105-900 Santa Maria, RS, Brazil
${ }^{3}$ Federal Institute of Santa Catarina/IFSC, Campus Urupema, Senadinho Road, Center, 88625-000 Urupema, SC, Brazil

Manuscript received on April 11, 2014; accepted for publication on August 12, 2015

\begin{abstract}
This work aims at evaluate ethanol effect of acetaldehyde application in post-storage quality of 'Royal Gala' apples maintenance, and to compare them with consolidated storage techniques. Thus two experiments were performed during the years of 2008 and 2009. In the first experiment (2008), the application of ethanol, acetaldehyde or 1-MCP and ethylene scrubbing were tested. Fruits were stored in controlled atmosphere (CA) with $1.0 \mathrm{kPa} \mathrm{O}_{2}$ and $2.0 \mathrm{kPa} \mathrm{CO}_{2}$ at $0.5^{\circ} \mathrm{C}$. In the second experiment (2009), the treatments tested were ethanol application combined or not with low relative humidity (LRH) and LRH alone. In this experiment, apples were stored in $\mathrm{CA}$ with $1.2 \mathrm{kPa} \mathrm{O}_{2}+2.5 \mathrm{kPa} \mathrm{CO}_{2}$ at $0.5^{\circ} \mathrm{C}$. After eight months of storage, $0.5 \mathrm{~mL}$ ethanol $\mathrm{kg}^{-1}$ apples month ${ }^{-1}$ or $0.25 \mathrm{~mL}$ acetaldehyde $\mathrm{kg}^{-1}$ apples month ${ }^{-1}$ increased mealiness, flesh browning, and decays incidence and reduced flesh firmness. In contrast, $0.3 \mathrm{~mL}$ ethanol $\mathrm{kg}^{-1}$ apples month ${ }^{-1}$, tested on second experiment, prevented fruit softening and decreased ACC oxidase activity and ethylene production. Although lower relative humidity was not efficient in maintaining poststorage quality, it enhanced the positive effect of ethanol application at $0.3 \mathrm{~mL} \mathrm{~kg}^{-1}$ apples month ${ }^{-1}$.
\end{abstract}

Key words: acetaldehyde, anaerobic respiration, ethylene, quality.

\section{INTRODUCTION}

In Brazil, the most important apple genotypes cultivated is Gala and its mutants, such as 'Royal Gala', which together represent approximately $60 \%$ of the total amount of apples produced in Brazil. Since apples are climacteric fruits, the ripening of these fruits continues after harvest. In order to extend the storage period ripening must be delay by storing fruits under low temperatures and controlled atmosphere (CA). However, the

Correspondence to: Anderson Weber

E-mail: anderson.weber@uffs.edu.br / anweba@gmail.com quality of apples after long-term storage under CA is not always maintained at the levels desired, especially when no additional storage techniques are combined to the CA storage (Brackmann et al. 2009).

So far, studies on the effect of ethanol and acetaldehyde on apples post-harvest quality are scarce. However, some studies have shown that non-toxic concentrations of ethanol exposition can decrease the respiration rate, ethylene synthesis (Asoda et al. 2009), chlorophyll degradation (Fukasawa et al. 2010) on broccolis, and the occurrence of decay and physiological disorders 
in tomato and carnation flowers (Pesis 2005). Ethanol application inhibits the expression of $B O$ $A C O 1, B O-A C O 2$ and $B O-A C S 1$ genes, which are involved in ethylene biosynthesis. Therefore, ethylene synthesis is inhibited by ethanol in broccolis (Asoda et al. 2009).

Relative humidity $(\mathrm{RH})$ reduction inside storage chamber induces transpiration and, consequently, leads fruits to lose water. Thus, free water amount into the intercellular spaces of fruits is decreased. This facilitated excessive levels of fermentation products diffusion. In this regard, Prange et al. (2001) observed that when the RH was reduced, during CA storage of apples, fruit respiration was decreased and the quality was maintained. In addition, storing fruits at $\mathrm{RH}$ levels close to $100 \%$, increasing the development of senescent breakdown and fungi infection (Brackmann et al. 2007).

Currently, there is a high demand for development of storage methods that are both affordable and accessible to most apple producers and storage facilities. These methods should also satisfy the increasing demand for high fruit quality. Thus the aim of this study was to verify the effect of ethanol and acetaldehyde application in low relative humidity on the quality of apples, comparing these effects with a conventional controlled atmosphere storage.

\section{MATERIALS AND METHODS}

Two experiments (one in 2008 and another in 2009) were carried out with 'Royal Gala' apples. These fruits were harvested from a commercial orchard in Vacaria, Rio Grande do Sul, Brazil. Apples were pre-selected and then transported to the research facility in Santa Maria. At harvest, an iodide-starch test (scale from 1 to 10 , where $1=$ green and $10=$ ripe) indicated that apples had an average ripening index of 6.72 and 4.54 in 2008 and 2009, respectively. In the first experiment, apples were stored under $\mathrm{CA}(1.0 \mathrm{kPa} \mathrm{O}$ and 2.0 $\mathrm{kPa} \mathrm{CO}$ ) at $0.5^{\circ} \mathrm{C}$. The treatments tested were: [1] CA (control); [2] CA with the supply of ethanol at the rate of $0.5 \mathrm{~mL} \mathrm{~kg}^{-1}$ apples month ${ }^{-1}$; [3] CA with the supply of acetaldehyde at $0.25 \mathrm{~mL} \mathrm{~kg}^{-1}$ apples month $^{-1}$; [4] CA combined with the application of $625 \eta \mathrm{L} \mathrm{L}^{-1}$ 1-MCP (1-methylcyclopropene) at the first day of storage; and [5] CA combined with ethylene scrubbing, which was maintained lower than $0.02 \mu \mathrm{L} \mathrm{L}^{-1}$.

In the second experiment, fruits were stored under $\mathrm{CA}\left(1.2 \mathrm{kPa} \mathrm{O}_{2}\right.$ and $\left.2.5 \mathrm{kPa} \mathrm{CO}_{2}\right)$ at $0.5^{\circ} \mathrm{C}$. The treatments tested in the second experiment were: [1] CA (control); [2] CA combined with low relative humidity (LRH) (92\%); [3] CA combined with LRH and with supply of ethanol at the rate of $0.3 \mathrm{~mL} \mathrm{~kg}^{-1}$ apples month ${ }^{-1}$; and [4] CA with ethanol supply at $0.3 \mathrm{~mL} \mathrm{~kg}^{-1}$ apples month ${ }^{-1}$.

In both experiments, samples were stored inside hermetically closed experimental chambers (volume of 0.232 or $0.400 \mathrm{~m}^{3}$ ). The $\mathrm{RH}$ was maintained at $96 \pm 1 \%$, except for the treatment with $\mathrm{LRH}$, which was maintained at $92 \pm 1 \%$. In order to decrease the RH during storage, calcium chloride ( $80 \mathrm{~g}$ per $13 \mathrm{~kg}$ apples) was placed inside the experimental chambers. This product was replaced by a new batch at the middle of the storage period. The treatment leads the fruit to lose $3 \%$ of their weight. The air temperature was controlled by electronic thermostats, and fruits temperature was daily checked with the help of thermometers introduced into fruits flesh. The $\mathrm{O}_{2}$ and $\mathrm{CO}_{2}$ levels were established exactly as described by Brackmann et al. (2009).

The supply of ethanol was carried out monthly at a rate of $0.5 \mathrm{~mL} \mathrm{~kg}^{-1}$ fruits (experiment I) or 0.3 $\mathrm{mL} \mathrm{kg}^{-1}$ fruits (experiment II) using ethyl alcohol $92.5 \%$. This compound was supplied by injecting the calculated amount through an opening onto a filter paper, which facilitated ethanol evaporation. Acetaldehyde was supplied in the same way by injecting $0.25 \mathrm{~mL} \mathrm{~kg}^{-1}$ apples month ${ }^{-1}$ of the product at $99.9 \%$. 
1-MCP was applied to apples right at the beginning of storage, when fruits were exposed to the product for 24 hours under $0.5^{\circ} \mathrm{C}$. The commercial product SmartFresh $^{\circledR}$ (Rohm \& Hass Co.), which contains $0.53 \%$ of $1-\mathrm{MCP}$, was used as 1-MCP source. To obtain the desired concentration of $625 \eta \mathrm{L} \mathrm{L}^{-1} 1-\mathrm{MCP}$, both the volume of the storage chamber and the concentration of the active ingredient were taken into account. In order to maintain low ethylene levels, during storage in treatment five (first experiment), pellets impregnated with potassium permanganate (commercial product Always Fresh $\AA$ ), were placed inside the experimental storage chamber. Ethylene concentrations inside the experimental chambers were assessed weekly by gas chromatography. The levels of this plant hormone in the ethylene scrubbing treatment were always below the detection limit $\left(<0.02 \mu \mathrm{L} \mathrm{L}^{-1}\right)$ of the gas chromatograph.

Ethylene synthesis and fruit respiration were analyzed after eight months of storage for both experiments. In addition, other parameters (including destructive analyses) were also assessed after this period of storage and after seven days of shelf-life at $20^{\circ} \mathrm{C}$. The following parameters were assessed: incidence of decay, senescent breakdown, mealiness, flesh firmness, total soluble solids (TSS), titratable acidity (TA), ethylene synthesis, activity of the ethylene-forming enzyme ACC oxidase and respiration rates. These analyses were carried out exactly as described by Brackmann et al. (2009).

Both experiments were carried out and analyzed following a completely randomized experimental design. Each treatment had four replicates containing 25 apples. Prior to ANOVA, all data was tested for normal distribution and homogeneity of error variances by Lilliefors and Bartlett tests, respectively. All data showing non-normal distribution were transformed by arc.sen, and those which not showed variances error homogeneity were transformed by $\log _{10}(\mathrm{x}$ $+1.0)$ before ANOVA. Means of Treatments were compared by Tukey test at 5\% probability. The statistical analyses were undertaken by the statistical software SisVar, Federal University of Lavras.

\section{RESULTS AND DISCUSSION}

After 8 months of storage, the supply of acetaldehyde decreased the synthesis of ethylene 12 hours after removing apples from storage, as compared to the control treatment (Figure 1a). However, in the evaluation after two days of shelf-life, this treatment did not differ statistically from the application of 1-MCP, and after four days acetaldehyde application provided the highest rate of ethylene production (Figure 1a). It is likely that this effect was directly related to the highest occurrence of physiological disorders, and decays in these fruits, which can increase respiration rates. This fact, possibly, is related to the higher incidence of physiological disorders and decay incidence, also causing an increase in the respiratory rate, equivalent to the control treatment (CA) (Figure 1c). The management of ethylene in the first experiment, either by ethylene scrubbing, during storage or application of 1-MCP, reduced the respiration rates up to the fourth day of shelflife at $20^{\circ} \mathrm{C}$ (Figure 1c). In experiment $\mathrm{I}$, the application of 1-MCP decreased ethylene-forming enzyme ACC oxidase activity (Table I). The supply of ethanol or acetaldehyde, in turn, did not alter the activity of this enzyme as compared to the storage under conventional CA (Table I).

In the second experiment, however, the supplementation of ethanol at $0.3 \mathrm{~mL} \mathrm{~kg}^{-1}$ apple month $^{-1}$ decreased the ACC oxidase activity, especially when this treatment was associated with LRH (Table I). As a consequence, the synthesis of ethylene was also reduced by this treatment (Figure 1b). Compared to control (conventional CA), the application of ethanol only decreased fruit respiration at the second day of shelf-life at $20^{\circ} \mathrm{C}$ 
(Figure 1d). Thus, it appears that this treatment is not very effective in reducing the metabolism of apples.

Titratable acidity was not affected by the treatments tested in experiment I. However, in experiment II, the levels of titratable acidity were the highest in apples stored under the supply of 0.3 $\mathrm{mL}$ ethanol $\mathrm{kg}^{-1}$ apple month ${ }^{-1}$ combined with LRH, even though these levels did not differ statistically from those apples stored only under LRH (Table I). Although, the relatively low effect of ethanol supply on the titratable acidity when apples are stored under LRH, the ethanol application enhances the quality attribute maintenance. Regarding the levels of TSS, at the experiment I, the apples stored under $\mathrm{CA}$ with additional treatments maintained higher levels of TSS as compared to CA alone (Table 1). In experiment II, the application of ethanol combined with LRH was more effective in maintaining higher levels of TSS after seven days of shelf-life at $20^{\circ} \mathrm{C}$ (Table I), indicating that this storage condition reduced the consumption fruits sugars. In addition, the use of LRH, during the storage, enhanced the loss of water by these fruits,
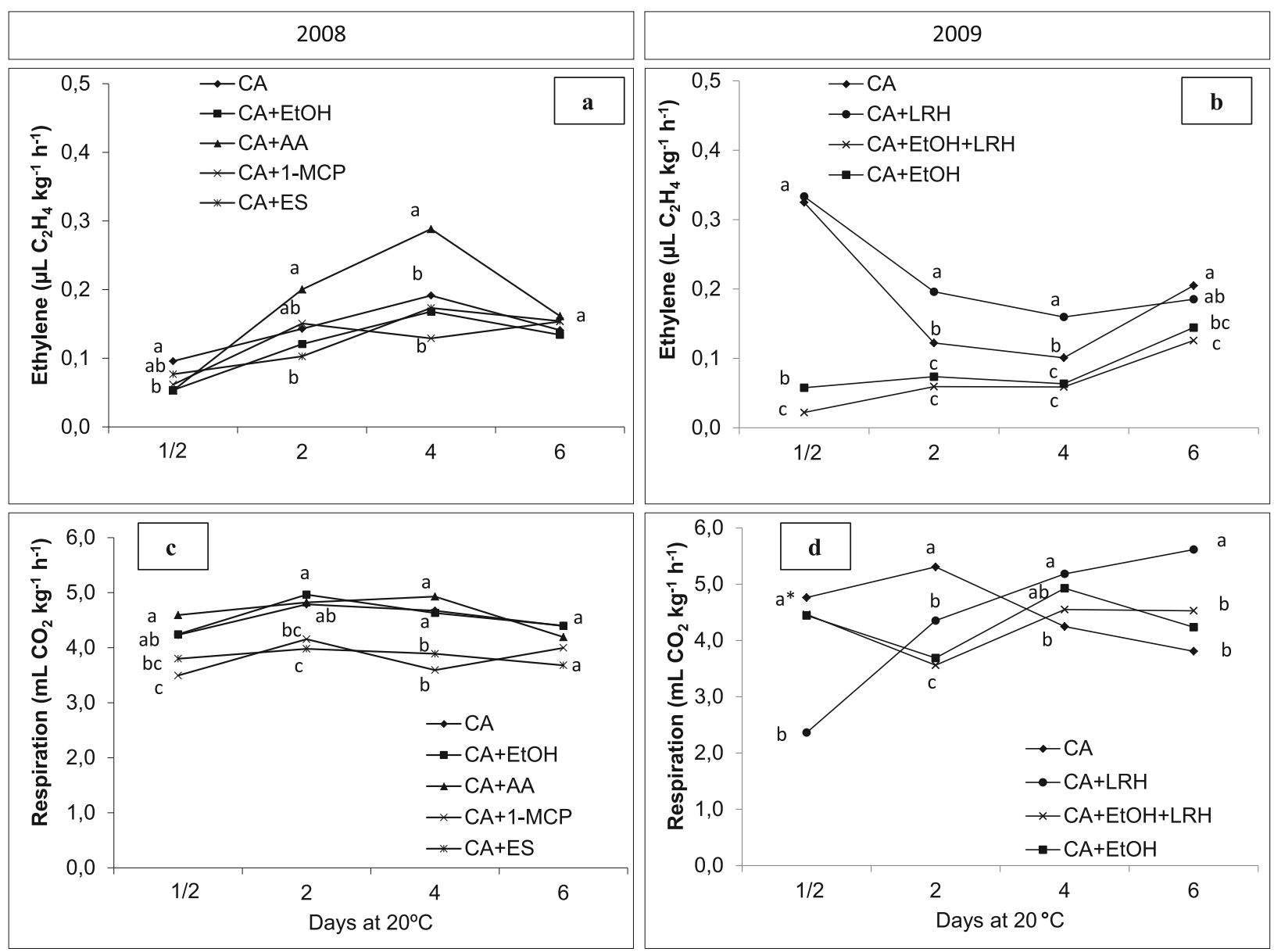

Figure 1 - Ethylene production (a and b, for the experiments of 2008 and 2009, respectively) and respiratory rate (c and $\mathbf{d}$ for the experiments of 2008 and 2009, respectively) of 'Royal Gala' apples stored for 8 months and then exposed during 6 days at $20{ }^{\circ} \mathrm{C}$.

* Treatments with means not followed by the same lowercase letter in the same evaluation date differ by Tukey's test at $5 \%$ probability. Initial analysis: ethylene: $1.33 \mu \mathrm{L} \mathrm{C}_{2} \mathrm{H}_{4} \mathrm{~kg}^{-1} \mathrm{~h}^{-1}$, respiration: $6.86 \mathrm{~mL} \mathrm{CO} \mathrm{kg}^{-1} \mathrm{~h}^{-1}$ for the experiment I and for the experiment II ethylene: $0.52 \mu \mathrm{L} \mathrm{C}_{2} \mathrm{H}_{4} \mathrm{~kg}^{-1} \mathrm{~h}^{-1}$, acetaldehyde; 1-MCP: 1-metylcyclopropeno; ES: ethylene scrubbing; LRH: low relative humidity. 
TABLE I

ACC oxidase activity, titratable acidity (TA), total soluble solids (TSS) and flesh firmness of 'Royal Gala' apples stored in controlled atmosphere for eight months and then exposed for seven days at 20 ${ }^{\circ} \mathrm{C}$. Santa Maria, 2008 and 2009.

\begin{tabular}{|c|c|c|c|c|}
\hline Treatment & $\begin{array}{l}\text { ACC oxidase activity } \\
\left(\eta \mathrm{L} \mathrm{C}_{2} \mathrm{H}_{4} \mathrm{~g}^{-1} \mathrm{~h}^{-1}\right)\end{array}$ & $\begin{array}{c}\text { TA } \\
\left(\text { meq } 100 \mathrm{~mL}^{-1}\right) \\
\end{array}$ & $\begin{array}{c}\text { TSS } \\
\left({ }^{\circ} \text { Brix }\right) \\
\end{array}$ & $\begin{array}{l}\text { Fresh firmness } \\
(\mathrm{N})\end{array}$ \\
\hline & \multicolumn{4}{|c|}{ 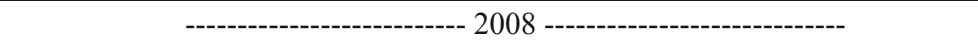 } \\
\hline Harvest** & 21.8 & 5.1 & 11.8 & 92.8 \\
\hline $\mathrm{CA}^{* * *}$ & $44.1 \mathrm{a}^{*}$ & $4.10 \mathrm{a}$ & $13.1 \mathrm{~b}$ & $79.1 \mathrm{a}$ \\
\hline $\mathrm{CA}+$ Ethanol & $37.8 \mathrm{a}$ & $4.10 \mathrm{a}$ & $13.8 \mathrm{a}$ & $74.3 \mathrm{~b}$ \\
\hline $\mathrm{CA}+$ Acetaldehyde & $39.7 \mathrm{a}$ & $3.98 \mathrm{a}$ & $13.8 \mathrm{a}$ & $76.0 \mathrm{ab}$ \\
\hline $\mathrm{CA}+1-\mathrm{MCP}$ & $20.8 \mathrm{~b}$ & $4.03 \mathrm{a}$ & $13.7 \mathrm{a}$ & $80.2 \mathrm{a}$ \\
\hline $\mathrm{CA}+$ ethylene scrubbing & $39.5 \mathrm{a}$ & $4.15 \mathrm{a}$ & $13.6 \mathrm{a}$ & $79.6 \mathrm{a}$ \\
\hline $\mathrm{CV}(\%)$ & 20.08 & 3.26 & 1.06 & 2.74 \\
\hline Harvest** & \multicolumn{3}{|c|}{------------------------------ 2009 ------------------------------- } & 99.3 \\
\hline $\mathrm{CA}^{* * *}$ & $39.8 a^{*}$ & $4.26 \mathrm{~b}$ & $13.2 \mathrm{c}$ & $76.9 \mathrm{~b}$ \\
\hline $\mathrm{CA}+\mathrm{LRH}^{* * * *}$ & $39.6 \mathrm{a}$ & $4.38 \mathrm{ab}$ & $13.6 \mathrm{~b}$ & $79.6 \mathrm{~b}$ \\
\hline $\mathrm{CA}+\mathrm{LRH}+$ Ethanol & $8.2 \mathrm{c}$ & $4.60 \mathrm{a}$ & $13.9 \mathrm{a}$ & $81.1 \mathrm{ab}$ \\
\hline $\mathrm{CA}+$ Ethanol & $17.3 \mathrm{~b}$ & $4.20 \mathrm{~b}$ & $13.4 \mathrm{bc}$ & $81.9 \mathrm{a}$ \\
\hline $\mathrm{CV}(\%)$ & 6.63 & 2.56 & 0.86 & 1.91 \\
\hline
\end{tabular}

* Treatments with means not followed by the same lowercase letter vertically differ by Tukey's test at $5 \%$ probability.

** Initial analysis performed prior to storage of fruits.

$* * * \mathrm{CA}$ : controlled atmosphere.

**** LRH: Low relative humidity $(92 \%)$.

thereby concentrating sugars and increasing levels of TSS. In melons, ethanol application increased sugars levels, especially sucrose, after four days of storage at $24^{\circ} \mathrm{C}$ (Liu et al. 2012). By contrast, ethanol supply on 'Red Globe' grapes had no effect on sugar levels (Ustun et al. 2012).

The supply of fermentation compounds, particularly ethanol, during the storage had a negative influence on flesh firmness in the first experiment (Table I). However, in the second experiment, the supply of lower doses of ethanol resulted in fruits with the highest flesh firmness after the storage (Table I). This discrepancy was most likely due to the different ethanol doses used during the two experiments. Hence the supply of ethanol at $0.5 \mathrm{~mL} \mathrm{~kg}^{-1}$ apple month ${ }^{-1}$ may have induced physiological injuries, since ethanol high levels are toxic to fruits (Pesis 2005). The positive effect of the ethanol treatment observed in the second experiment is in agreement with the study carried out by Bai et al. (2011) with apples and Ritenour et al. (1997) with melons. In these studies, the supply of ethanol and/or acetaldehyde maintained the highest flesh firmness. In this regard, it has been reported that enzymes activities related to cell wall degradation, such as polygalacturonases, are reduced by ethanol in peaches, nectarines (Lurie and Pesis 1992) and tomatoes (Pesis and Marinansky 1992). Furthermore, the acetaldehyde supply in avocado decreased cell wall-hydrolyzing enzymes activity, such as polygalacturonases, ß-galactosidases and endoglucanases (Pesis et al. 1998).

Most of decay incidence is caused by Penicillium sp.,which was increased by the application of acetaldehyde or ethanol on experiment I after 7 days of shelf-life at $20^{\circ} \mathrm{C}$ (Table II). This result is in disagreement with those reported by El-Sheikh Aly 
TABLE II

\begin{tabular}{|c|c|c|c|c|}
\hline \multirow[b]{2}{*}{ Treatment } & \multicolumn{2}{|c|}{ Decay $(\%)$} & \multirow{2}{*}{$\begin{array}{c}\text { Flesh } \\
\text { breakdown } \\
(\%)\end{array}$} & \multirow[b]{2}{*}{$\begin{array}{c}\text { Mealiness } \\
(\%)\end{array}$} \\
\hline & $\begin{array}{c}\text { Chamber } \\
\text { opening }\end{array}$ & $\begin{array}{l}\text { Seven days at } \\
20^{\circ} \mathrm{C}\end{array}$ & & \\
\hline & \multicolumn{4}{|c|}{------------------------------- 2008 ---------------------------------- } \\
\hline $\mathrm{CA}^{* *}$ & $1.3 \mathrm{a}^{*}$ & $4.0 \mathrm{~b}$ & $6.3 \mathrm{~b}$ & $6.5 \mathrm{bc}$ \\
\hline $\mathrm{CA}+$ Ethanol & $1.3 \mathrm{a}$ & $18.0 \mathrm{a}$ & $15.5 \mathrm{ab}$ & $23.2 \mathrm{a}$ \\
\hline $\mathrm{CA}+$ Acetaldehyde & $11.3 \mathrm{a}$ & $41.0 \mathrm{a}$ & $21.2 \mathrm{a}$ & $14.1 \mathrm{ab}$ \\
\hline $\mathrm{CA}+1-\mathrm{MCP}$ & $1.3 \mathrm{a}$ & $3.7 \mathrm{~b}$ & $6.7 \mathrm{~b}$ & $2.9 \mathrm{c}$ \\
\hline $\mathrm{CA}+$ ethylene scrubbing & $2.4 \mathrm{a}$ & $3.8 \mathrm{~b}$ & $4.9 \mathrm{~b}$ & $12.3 \mathrm{~b}$ \\
\hline $\mathrm{CV}(\%)$ & 77.86 & 36.39 & 32.45 & 26.94 \\
\hline \multicolumn{5}{|c|}{ 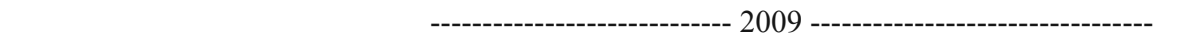 } \\
\hline $\mathrm{CA}+\mathrm{LRH}^{* * *}$ & $0.0 \mathrm{a}$ & $9.0 \mathrm{a}$ & $3.0 \mathrm{~b}$ & $7.0 \mathrm{a}$ \\
\hline $\mathrm{CA}+\mathrm{LRH}+$ Ethanol & $0.0 \mathrm{a}$ & $3.0 \mathrm{a}$ & $7.0 \mathrm{a}$ & $10.0 \mathrm{a}$ \\
\hline $\mathrm{CA}+$ Ethanol & $2.0 \mathrm{a}$ & $3.0 \mathrm{a}$ & $7.0 \mathrm{a}$ & $7.2 \mathrm{a}$ \\
\hline $\mathrm{CV}(\%)$ & 40.3 & 48.7 & 20.2 & 21.7 \\
\hline
\end{tabular}

* Treatments with means not followed by the same lowercase letter vertically differ by Tukey's test at $5 \%$ probability.

** CA: controlled atmosphere.

*** LRH: Low relative humidity $(92 \%)$.

and Baraka al. (2000), who observed that Botrytis cinerea and Monilia fructicola growth on peaches was slowed down by the acetaldehyde application. The same authors also observed that the growth of Monilia fructicola mycelia was completely inhibited by immersing fruits into a $40 \%$ acetaldehyde solution. It is noteworthy in the present study the high level of acetaldehyde supplied to apples, during the first experiment, induced the occurrence of mealiness and flesh breakdown (Table II). These two physiological disorders may have increased fruits susceptible to the penetration and subsequent infection by pathogens. Regarding ethanol, many reports have shown that this compound can decrease decay occurrence in many fruit species, including peaches, citrus, cherries and grapes (Smilanick et al. 1995, Romanazzi et al. 2007, Bai et al. 2011, Candir et al. 2012). In addition, since ethanol is a natural compound, it can be applied to fruits even during the post-harvest period (Pesis 2005). However, the results of the present work show that the supply of ethanol to apples was not able to reduce the incidence of decay in 'Royal Gala' apples (Table II), suggesting that this compound may not be efficient in preventing decays in apples.

Flesh breakdown occurrence, during experiment I was the highest in apples treated with 0.25 $\mathrm{mL}$ acetaldehyde $\mathrm{kg}^{-1}$ apples month ${ }^{-1}$, although not differing from the ethanol treatment (Table II). During experiment II, in turn, the effect of ethanol supply at $0.3 \mathrm{~mL} \mathrm{~kg}^{-1}$ apples month ${ }^{-1}$ was not different from the control treatment, whereas the storage under LRH resulted in the lowest occurrence of this physiological disorder (Table II). It has also been shown that the loss of fruit mass, due to the use of LRH, during storage, can decrease the occurrence of senescent breakdown in 'Royal Gala' apples (Brackmann et al. 2007) and 'Laetitia' plums (Alves et al. 2010).

During the first experiment, ethanol treatment resulted in the highest occurrence of mealiness (Table II). This treatment effect, however, was not 
different from acetaldehyde application (Table II). The lowest mealiness occurrence was obtained by treating apples with 1-MCP, although it did not differ from control (Table II).Mealiness development is usually associated with an advanced stage of ripening. As fruits ripen, insoluble pectins from the middle lamella are progressively transformed into soluble pectins, thereby decreasing the cohesive strength between fruit cells, and contributing to mealiness development (Prasanna et al. 2007). Franck et al. (2007) have reported on physiological disorders related to fruit senescence, such as senescent breakdown and mealiness. According to these authors, these disorders are directly related to ethanol concentrations detected in pears cortex. However, Fernandez-Trujillo et al. (2001) and Argenta et al. (2002) have observed that the accumulation of fermentation products, such as ethanol and acetaldehyde, is not the direct trigger of internal breakdown in the cortex of apples. In fact, the existence of a direct involvement of fermentation products on the development of physiological disorders has not yet been proven. However, most likely cause of internal breakdown in fruits is not the accumulation of ethanol, during anaerobic respiration, but rather energy deprivation which is associated with this type of metabolism. As consequence, anaerobic conditions decrease the reduction potential of cells, which is required for defense, membrane repair and biosynthetic reactions (Pedreschi et al. 2009). Physiological disorders in fruits, such as internal browning, are the consequence of an impaired energy metabolism in cells (Saquet et al. 2003, Franck et al. 2007). In addition, a reduction in ATP synthesis induces damages in cell membranes and causes defective cell compartmentalization (Ho et al. 2013.).

Concluding, the application of ethanol $(0.5$ $\mathrm{ml} \mathrm{kg}{ }^{-1}$ apples month $\left.{ }^{-1}\right)$ or acetaldehyde $(0.25 \mathrm{ml}$ $\mathrm{kg}^{-1}$ apples month ${ }^{-1}$ ), during storage, had a negative effect on the post-storage quality of 'Royal Gala' apples stored during eight months under controlled atmosphere. However, the supply of $0.3 \mathrm{ml}$ ethanol $\mathrm{kg}^{-1}$ apples month ${ }^{-1}$ improved the post-harvest quality of 'Royal Gala' apples. Although lowering the relative humidity, during storage, had only a minor effect on the quality of 'Royal Gala' apples but, when combined to $0.3 \mathrm{ml}$ ethanol $\mathrm{kg}^{-1}$ fruit month $^{-1}$, this treatment enhanced the positive effect of ethanol application.

\section{RESUMO}

O objetivo deste trabalho foi avaliar o efeito do etanol ou aplicação de aldeído acético na manutenção da qualidade pós-colheita de maçãs 'Royal Gala', e compará-los a técnicas de armazenamento consolidadas. Assim, dois experimentos foram realizados durante os anos de 2008 e 2009. No primeiro experimento (2008), foi testada a aplicação de etanol, aldeído acético ou 1-MCP e a absorção de etileno. Os frutos foram armazenados em atmosfera controlada (AC) com $1,0 \mathrm{kPa} \mathrm{O}_{2}$ e 2,0 $\mathrm{kPa} \mathrm{CO}$ em $0,5{ }^{\circ} \mathrm{C}$. No segundo experimento (2009), os tratamentos testados foram a aplicação de etanol combinado ou não com baixa umidade relativa do ar (BUR) e somente BUR. Nesse experimento, as maçãs foram armazenadas em AC com 1,2 $\mathrm{kPa} \mathrm{O}_{2}+2,5 \mathrm{kPa}$ de $\mathrm{CO}_{2}$ em $0,5^{\circ} \mathrm{C}$. Após oito meses de armazenamento, $0,5 \mathrm{ml}$ de etanol $\mathrm{kg}^{-1}$ maçãs mês ${ }^{-1}$ ou $0,25 \mathrm{~mL}$ de aldeído acético $\mathrm{kg}^{-1}$ maçãs mês ${ }^{-1}$, aumentaram a incidência de polpa farinácea, escurecimento da polpa e podridões, e diminuiu a firmeza da polpa. Por outro lado, a 0,3 $\mathrm{ml}$ de etanol $\mathrm{kg}^{-1}$ maçãs mês ${ }^{-1}$, testadas no segundo experimento, impediu o amolecimento das frutas e diminuiu da atividade da ACC oxidase e produção de etileno. Embora a baixa umidade relativa do ar não tenha sido eficiente na manutenção da qualidade pós-colheita, aumentou o efeito positivo da aplicação de $0,3 \mathrm{~mL}$ de etanol $\mathrm{kg}^{-1}$ maçãs mês ${ }^{-1}$.

Palavras-chave: aldeído acético, respiração anaeróbica, etileno, qualidade.

\section{REFERENCES}

Alves EO, Steffens CA, Amarante CVt, Weber A, MIQUELOTO A AND BRACKMANN A. 2010. Cold storage of 'Laetitia' plums treated with 1-MCP and induced to loss of fresh mass. Ciência Rural 40: 30-36. 
ARGENTA LC, FAN X AND MATTHEIS JP. 2002. Responses of 'Fuji' apples to short and long duration exposure to elevated $\mathrm{CO}_{2}$ concentration. Postharvest Biol and Tec 24: 13-24.

ASODAT, TERAI H, KATO M AND SUZUKI Y. 2009. Effects of postharvest ethanol vapor treatment on ethylene responsiveness in broccoli. Postharvest Biol Tec 52: 216220.

BAi J, Plotto A, SPotTs R AND RATtANAPANONE N. 2011. Ethanol vapor and saprophytic yeast treatments reduce decay and maintain quality of intact and fresh-cut sweet cherries. Postharvest Biol Tec 62: 204-212.

Brackmann A, Pinto JAV, Weber A, Neuwald DA AND STEFFENS CA. 2007. Induction of loss fresh mass and physiological disorders in 'Royal Gala' apple during controlled atmosphere storage. Revista Brasileira de Armazenamento 32: 87-92.

Brackmann A, Weber A, Sestari i, Peterle Me, BOTH V, PAVANELO EP AND PINTO JAV. 2009. Ethylene management and its relation with ripening of 'Gala' apples stored on controlled atmosphere. Bragantia 68: 519-525.

CAndir E, Ozdemir AE, Kamiloglu O, Soylu EM, DiLBAZR ANDUSTUND. 2012. Modified atmosphere packaging and ethanol vapour to control decay of 'Red Globe' table grapes during storage. Postharvest Biol Tec 63: 98-106.

EL-SHEIKH ALY MM AND BARAKA MA. 2000. The effectiveness of fumigants and biological protection of peach against fruit rots. Assiut J Agric Sci 3: 19-31.

FERNANDEZ-TRUJILLO JP, NOCK JF AND WATKINS CB. 2001. Superficial scald, carbon dioxide injury, and changes of fermentation products and organic acids in 'Cortland' and 'Law Rome' apples after high carbon dioxide stress treatment. J Am Soc Hortic Sci 126: 235-241.

FRANCK C, LAMMERTYN J, HO QT, VERBOVEN P, VERLINDEN B AND NICOLAÏ BM. 2007. Browning disorders in pear fruit. Postharvest Biol Tec 43: 1-13.

FUKASAWA A, SUZUKI Y, TERAI H AND YAMAUCHI N. 2010. Effects of postharvest ethanol vapor treatment on activities and gene expression of chlorophyll catabolic enzymes in broccoli florets. Postharvest Biol Tec 55: 97-102.

Ho QT, Verboven P, Verlinden BE, SCHENK A AND NICOLAÏ BM. 2013. Controlled atmosphere storage may lead to local ATP deficiency in apple. Postharvest Biol Tec 78: 103-112.

LIU WW, QI HY, XU BH, LI Y, TIAN XB, JIANG YY, XU XF AND LV DQ. 2012. Ethanol treatment inhibits internal ethylene concentrations and enhances ethylester production during storage of oriental sweet melons (Cucumismelovar. Makuwa Makino). Postharvest Biol Tec 67: 75-83.

LURIE S AND PESIS E. 1992. Effect of acetaldehyde and anaerobiosis as postharvest treatments on the quality of peaches and nectarines. Postharvest Biol Tec 1: 317-326.

PEDRESCHI R, FRANCK C, LAMMERTYN J, ERBAN A, KOPKA J, Hertog M, Verlinden B AND NiCOLAÏ B. 2009. Metabolic profiling of 'Conference' pears under low oxygen stress. Postharvest Biol Tec 51: 123-130.

PESIS E. 2005. The role of the anaerobic metabolites, acetaldehyde and ethanol, in fruit ripening, enhancement of fruit quality and fruit deterioration. Postharvest Biol Tec 37: 1-19.

PESIS E, FAIMAN D AND DORI S. 1998. Postharvest effects of acetaldehyde vapor on ripening-related enzyme activity in avocado fruit. Postharvest Biol Tec 13: 245-253.

PESIS E AND MARINANSKY R. 1992. Carbon dioxide and ethylene production in response to acetaldehyde and ethanol treatments in grapes. J Am Soc Hortic Sci 117: 110-113.

PRANGE RK, DE LONG JM AND HARRISON PA. 2001. Storage humidity and post-storage handling temperature affect bruising and other apple quality characteristics. ActaHorticulturae 553: 717-720.

PRASANNA V, PRABHA TN AND THARANATHAN RN. 2007. Fruit Ripening Phenomena-An Overview. Crit Rev Food Sci 47: 1-19.

RITENOUR MA, MANGRICH ME, BEAULIEU AR AND SALTVEIT ME. 1997. Ethanol effects on the ripening of climacteric fruit. Postharvest Biol Tec 12: 35-42.

ROMANAZZI G, KARABULUT OA AND SMILANICK JL. 2007. Combination of chitosan and ethanol to control postharvest gray mold of table grapes. Postharvest Biol Tec 45: 134140.

SAQUET AA, StReif J AND BANGerTh F. 2003. Energy metabolism and membrane lipid alterations in relation to brown heart development in Conference pears during delayed controlled atmosphere storage. Postharvest Biol Tec 30: 123-132.

SMILANICK JL, MARGOSAN DA AND HENSON DJ. 1995. Evaluation of heated solutions of sulfur dioxide, ethanol, and hydrogen peroxide to control postharvest green mold of lemons. Plant Diseases 79: 742-747.

USTUN U, CANDIR E, OZDEMIR AE, KAMILOGLU O, SOYLU EM AND DILBAZ R. 2012. Effects of modified atmosphere packaging and ethanol vapor treatment on the chemical composition of 'Red Globe' table grapes during storage. Postharvest Biol Tec 68: 8-15. 